\title{
Creative Writing in the Classroom: On Twitter, Aphorisms, Flash Fiction and Haiku
}

\author{
Josep Maria Rodríguez ${ }^{1, *}$, María Salvador ${ }^{2}$ \\ ${ }^{1}$ Universitat de Lleida, Spain. \\ ${ }^{2}$ Harvard University, USA.
}

How to cite this paper: Josep Maria Rodríguez, María Salvador. (2021). Creative Writing in the Classroom: On Twitter, Aphorisms, Flash Fiction and Haiku. The Educational Review, USA, 5(3), 76-78.

DOI: 10.26855/er.2021.03.007

Received: February 4, 2021

Accepted: February 28, 2021

Published: March 29, 2021

Corresponding author: Josep Maria Rodríguez, Universitat de Lleida, Spain. Email: josepmaria.rodriguez@udl.cat

\begin{abstract}
This article proposes creative writing workshops focused on brief literary formats as a method for fostering the reading habit of the students of today. As digital natives, they have become used to a certain brevity that can be used for the teacher's advantage. Three specific literary formats are considered as ideal for this activity: the aphorism, flash fiction, and the haiku. This article describes these brief literary forms and proposes how they can be used for furthering the students' interest in reading, as well as how it will benefit their overall skills as world citizens. Writing brief compositions in the form of aphorisms, haiku or flash fiction will improve the students' communication skills while becoming an entry point to literature itself in a range of genres, from philosophy, to narrative fiction, and poetry. Finally, this article considers a new online landscape that reflects a literary classroom through submissions and collaborations.
\end{abstract}

\section{Keywords}

Creative Writing, Haiku, Flash Fiction, Aphorism, Digital Natives, Writing Workshop, Twitter

\section{Introduction}

Every year, the platform We Are Social releases a digital report analyzing the trends and evolution of the use of the Internet and social media. Because it is a changing and complex landscape, reports such as We Are Social's are helpful in their offering of insight to such evolution. The data from 2020 show that Americans between 16 and 64 years old spend 6 hours and 42 minutes online on average every day, with over two of those hours being spent on social media.

One of the most frequented websites-albeit not as popular as YouTube, Facebook, or Amazon-is Twitter. Twitter's relevance is such that nowadays there are barely any politicians who do not use it to communicate to the masses, taking advantage of Twitter's main feature: its brevity. Because of this very attribute, each tweet can be a slogan. Originally, tweets were limited to 140 characters, but since 2017, Twitter granted its users the ability to write up to 280 characters - although in some linguistic environments the previous limitation of 140 characters is still enforced, such as the Chinese, Korean, and Japanese-speaking worlds.

Marshall McLuhan stated in his then polemic Understanding Media: The Extensions of Man (1964) that lineal, Gutenbergian, thought was coming to an end. The Internet has proven him right. The attention span of digital natives - using the term popularized by Marc Prensky (2010)—is unfocussed and disperse. In consequence, their engagement with content has become more shallow as well. Technological stimuli that reach us are many and constant. Of course, these stimuli affect school-aged children. It is our impression that the great novels by Tolstoy, Dickens or Proust are becoming increasingly higher mountain peaks, and thus harder to climb.

However, it is true that reading methods have undergone transformations throughout the centuries. For example, in 
the fourth century, Augustine of Hippo (354-430 AD) was horrified when he went to visit the Bishop of Milan-who would later be known as Saint Ambrose-because he found the Bishop sitting, reading in silence. The Bishop's attitude and silence annihilated the assumptions that had been fostered by classical culture, its rhetoric and oratory, and its public voice, because for the longest time writing itself had not influenced literary reading, which had continued to keep its oral quality (Valverde, 1982).

Therefore, the path we ought to follow now might not consist of demonizing the Internet and social media but on utilizing instead its influence and strengths to our teaching benefit—although, of course, from the belief that abusing technology does not make our classes more innovative nor better. The question we need to ask ourselves is, thus, how should we do it?

\section{Writing is reading}

One of the main areas of intervention for teachers of language and literature is encouraging students to read. A stable reading practice among children and teenagers allows their access to all branches of knowledge and aesthetical education, while developing reading comprehension and their communication skills-which in turn improves their academic performance - as well as a series of abilities, attitudes, and competences that are absolutely necessary for life in society. Moreover, such a stable habit of reading encourages critical thinking, while providing an outlook towards diversity in the world that stimulates an active and democratic exercise of citizenship.

Many authors have pointed to creative writing as the best option for children to become interested in reading-and to improve their reading comprehension as well (Moreno, 1994; Lorente, 2020; Rodríguez, 2020). This point connects, to certain extent, with Carol Chomsky’s (1971) famous apothegm: "Write first, read later."

Such is our new goal: to educate in literature - and, therefore, in literary reading — through creative writing. In doing this, students are no longer passive subjects but become instead in the protagonists of literature itself. In order to achieve this victory we are going to cede the playing field to them. Our pedagogical proposal consists of approaching literature through the parameters established by Twitter, i.e., 280 characters. This is a limitation that, without a doubt, allows us to avoid our students' reservations to creative writing. We insist: they only have to write 280 characters!

\section{Aphorism, flash fiction, haiku}

In Twilight of the Idols (1888), Friedrich Nietzsche (1983) defends saying in only ten sentences what others take a whole book to say. Each one of those sentences is an aphorism. We could define aphorisms as a hyper-brief prose, which flees from any narrative or discursive qualities as much as it runs from the fictional. The aphorism is, in short and in a simplified manner, a thought. However, the aphorism is a thought that does not have to negate expressive beauty, inventiveness or humor. The Polish master of aphorism, Stanisław Jerzy Lec (2014), has some good examples: "The freedom of the slaves is measured by the length of their chains", or "Since the moment man stood up, everything is posture".

The similarities with Twitter are obvious, even though Lec wrote his aphorisms at the end of the fifties and beginning of the sixties of the twentieth century. However, Lec's aphorisms are still current because they reveal something about ourselves, as individuals or as a collective. In fact, we could almost say that aphorisms—in general, not just Lec's-are well-dressed tweets. This is the reason why they constitute the first step in our attempt to turn literature into something alive. With this first exercise for a literary workshop, our students will improve their ability to analyze and reflect on their daily lives, on top of boosting their linguistic concretion, accuracy in the delivery of their message, wordplay, and other communicative skills.

Starting off from that idea of limited text, of those 280 characters of maximum length, we inevitably arrive to flash fiction. If aphorism has a gnomic character, flash fiction is all about narration: it is composed of drops of literary fiction. The goal would be that students would set up a narration with just a few words, just like that famous tale in the form of an advertisement: "For sale: baby shoes, never worn," which is sometimes attributed to Hemingway (Gilead, 2008, p. 119). Another example would be the incredibly brief text by the Argentinian author Andrés Neuman (2006) titled "Terror Novel": "When I woke up I had just been shaven".

Students will get into the art of narration by writing flash fiction, an activity through which they will design their own stories and characters. In narrating their own stories, students will in turn develop intertextuality, getting to know or even master ellipsis and other literary devices, including the metaphor. This will, without a doubt, become an entry point to poetry. Because at the endpoint to our journey through the briefest of the literary forms stands poetry itself, and more specifically, haiku.

A haiku is a three-verse poem. Defining haiku beyond that is a complex matter, because as Cor van den Heuvel states, "ultimately haiku eludes definition” (2000, LVI). Haiku, depending on the students' age, can be used as a three-verse 
poem that merely states the maximum amount of things in the minimum possible space-as defended by Jack Kerouac (Bevilacqua, 1994) — or we can instead bring it closer to the Japanese tradition whence it originates, as an objective experience of nature. A couple of examples should illustrate haiku's possibilities. On the one hand, Alan Pizzarelli's poem: "Twilight/staples rust/in the telephone pole" (Van den Heuvel, 2000, p. 155). And, on the other hand, Nicholas Virgilio's example: “The blind musician/extending an old tin cup/collects a snowflake” (Van den Heuvel, 2000, p. 255).

\section{Conclusion}

With the literary workshop as a starting point, our pedagogical proposal centers on the formats of the aphorism, flash fiction, and haiku. Although we could have cited Horace's Ars poetica (19 BC) or Baltasar Gracián's Oráculo manual y arte de prudencia (1647) in order to praise the benefits of brevity, we have preferred to connect this trait to the three subgenres mentioned above so they can be linked to Twitter and the new readers: that digital generation that we encounter in the classroom on a daily basis-a generation that is used to constant, brief stimuli.

Brief literary forms do not demand too much effort in terms of decoding if we compare them to standard narration or poetry, and they thus facilitate reading comprehension. Moreover, creative writing turns the students into the protagonists, which is of course a motivating element for them. Even more so if we also introduce a dialogical reading in the classroom based on the texts they create.

Literature is thus transformed into an interactive game for our students-it is widely known: kids like to play. In order to level up, they will require models to follow and, therefore, they will have to read. Literary education will become education in reading itself and the building up of a reading habit, while also nurturing their aesthetic, cultural and, by extension, social education.

To finish, just one idea, perhaps a wish: what if once these aphorisms, flash fictions and haikus are written, they are shared online? In the event that the students did not have a Twitter account, one could be created from and for the classroom. Building up from there, what if all classes, and all schools, engaged in the same activity, i.e., filling social media with literature?

The resulting landscape could be something like a sky filled with colorful balloons.

\section{References}

Bevilacqua, Emanuele. (1994). Guida alla beat generation. Roma: Theoria.

Chomsky, Carol. (1971). “Write first, read later”. Childhood Education, 47, 296-299.

“Digital 2020”. https://wearesocial.com/us/digital-2020-us.

Gilead, Amihud. (2008). “How Few Words Can the Shortest Story Have?”. Philosophy and Literature, 32(1), $119-129$.

Lec, Stanisław Jerzy. (1996). Pensamientos despeinados. Valencia: Pre-Textos.

Lorente, Jaime. (2020). El haiku en las aulas: Una guía metodológica. Toledo: Haijin Books.

McLuhan, Marshall. (1964). Understanding Media: The Extensions of Man. Cambridge (MA): The MIT Press.

Moreno, Víctor. (1994). El deseo de escribir: Propuestas para despertar y mantener el gusto por la escritura. Pamplona: Pamiela.

Neuman, Andrés. (2006). Alumbramiento. Madrid: Páginas de espuma.

Nietzsche, Friedrich. (1983). Twilight of the Idols/The Anti-Christ. London: Penguin.

Prensky, Marc. (2010). Teaching Digital Natives: Partnering for Real Learning. Thousand Oaks (CA): Corwin Press.

Rodríguez, Josep M. (2020). “El haiku y su valor instrumental en el aula”. Lenguaje y textos, 52, 1-8.

Valverde, José María. (1982). La literatura: Qué era y qué es. Barcelona: Montesinos.

Van den Heuvel, Cor. (2000). The Haiku Anthology. New York: Norton. 